\section{LITERATURE CITED}

American Ornithologists' Union. 1957. Checklist of North American birds. 5th ed. Baltimore.

Belcher, Boswell. 1957. Seen by a seer. Tha Blue Jay, 15:99.

Belcher, Margaret. 1958. Bird notes from a farm shelterbelt: The Blue Jay, 16:101-104.

Belcher, Margaret. 1961. Birds of Regina. Sask. Nat. Hist. Soc. Spec. Publ. \#3, Regina.

Bent, A. C. 1948. Life histories of North American nuthatches, wrens, thrashers, and their allies. U.S. Nat'I. Mus. and Smithsonian Inst., Washington.

Callin, E. M. 1962. Mockingbird at Fort Qu'Appelle. The Blue Jay, 20:111.

Findley, J. S. 1949. Mockingbirds in South Dakota. S.D. bird notes, 1(3):43.

Godfrey, W. Earl. 1950. Birds of the Cypress Hills and Flotten Lake Regions, Saskatchewan. King's Printer, Ottawa.

Greene, G. K., 1964. Mockingbird at Elbow. The Blue Jay, 22:6.

Hatch, David, ed. 1963. First Manitoba Christmas Count, 1962. The Blue Jay, 21:24-26.

Lahrman, Fred W. 1959. A report on spring migration in the Regina area. The Blue Jay, 17:96-98.

Potter, Laurence B. 1943a. Saskatchewan bird records made since the publication of
Mitchell's Catalogue of Saskatchewan birds in 192.4. The Blue Jay, 1(3):25.

Potter, Laurence B. 1943b. Bird notes from south-western Saskatchewan. Can. FieldNaturalist, 57:69-72.

Ridgway, Robert. 1907. The birds of North and Middle America, Part IV. Govt. Printing Office, Washington.

Roberts, T. S. 1936. The birds of Minnesota, Minneapolis, University of Minnesota Press.

Roy, Frank. 1958. Mockingbirds at Saskatoon. The Blue Jay, 16:108.

Sơlt, W. Ray, and A. L. Wilk. 1958. Birds of Alberta. Queen's Printer, Edmonton.

Stevens, O. A. 1948. New and unusual North Dakota trapping records. Auk, 65:136-7.

Viala, Auguste. 1963. Mockingbird at P.A. The Blue Jay, 21:14.

Wing, Leonard C. 1956. Natural history of birds. New York, The Ronald Press.

Wood, Norman A. 1923. Bird life of North Dakota. Univ. of Michigan Misc. Publ. 10:1-96.

Note: In the tables and the text of the paper there are further references to short notes without authors' names from the following journals-Audubon Field Notes, Audubon Magazine, The Auk, The Condor, The Flicker, South Dakota Bird Notes. Also, I have referred to Hugh Boyd's "About Birds", column in the Leader-Post, 1933-1937.

\title{
Killdeer Photos
}

\section{by Robert R. Taylor, Regina}

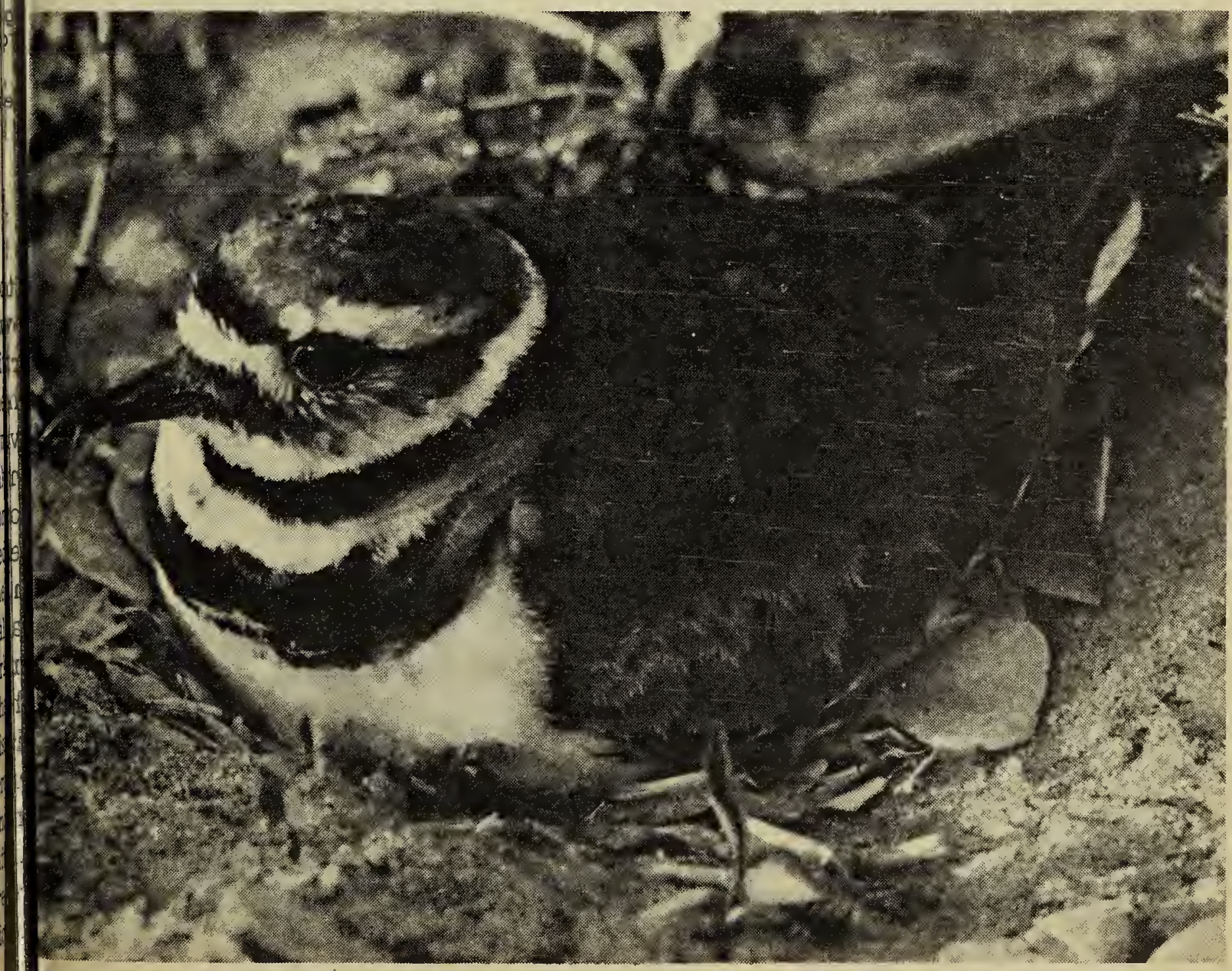



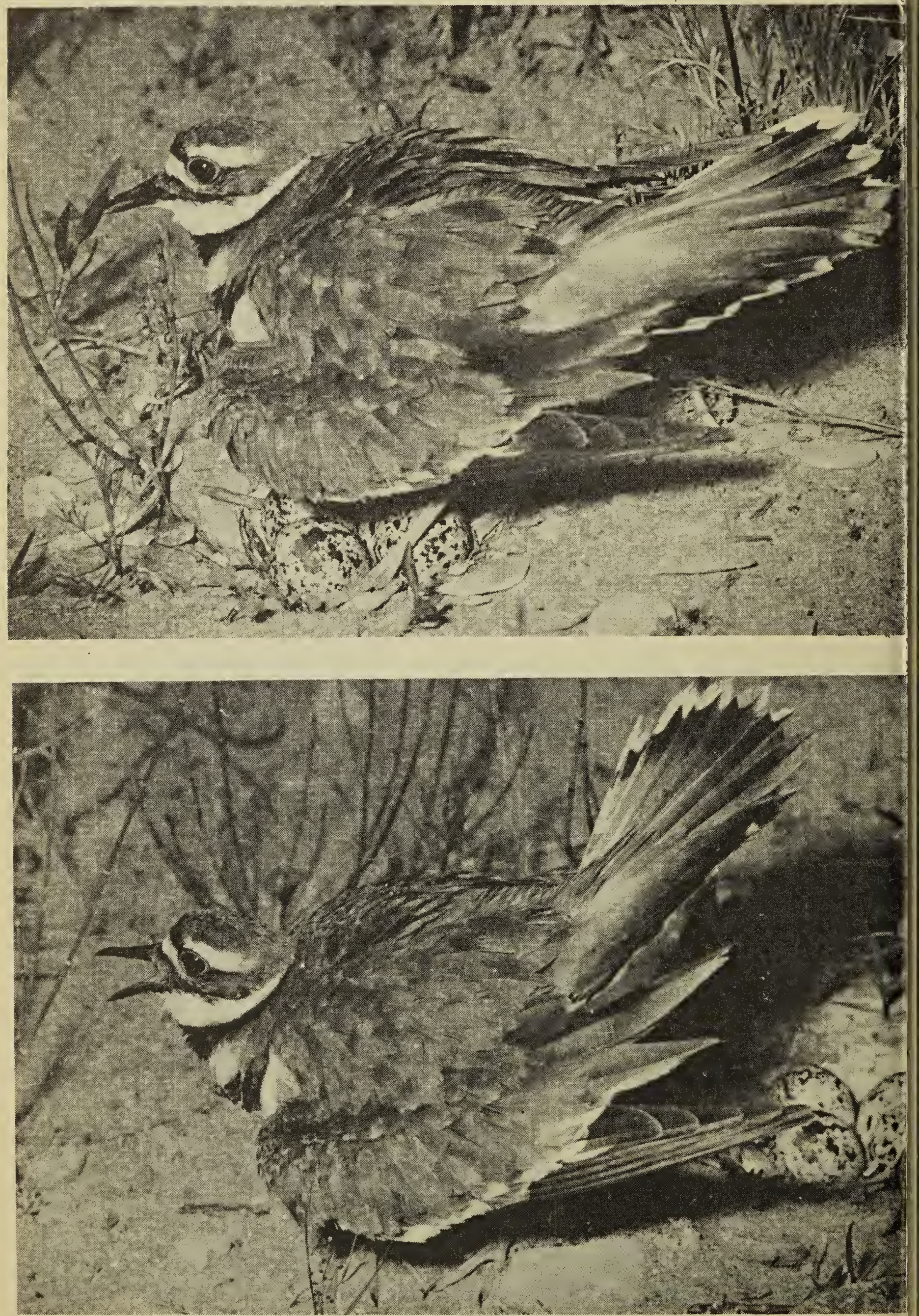